\title{
Antibacterial Agents
}

\section{Bio-Organometallic Derivatives of Antibacterial Drugs}

Miguel A. Sierra, ${ }^{*[a, c]}$ Luis Casarrubios, ${ }^{[a, c]}$ and María C. de la Torre ${ }^{[b, c]}$

Dedicated to Professor Ernesto Carmona on the occasion of his 70th birthday

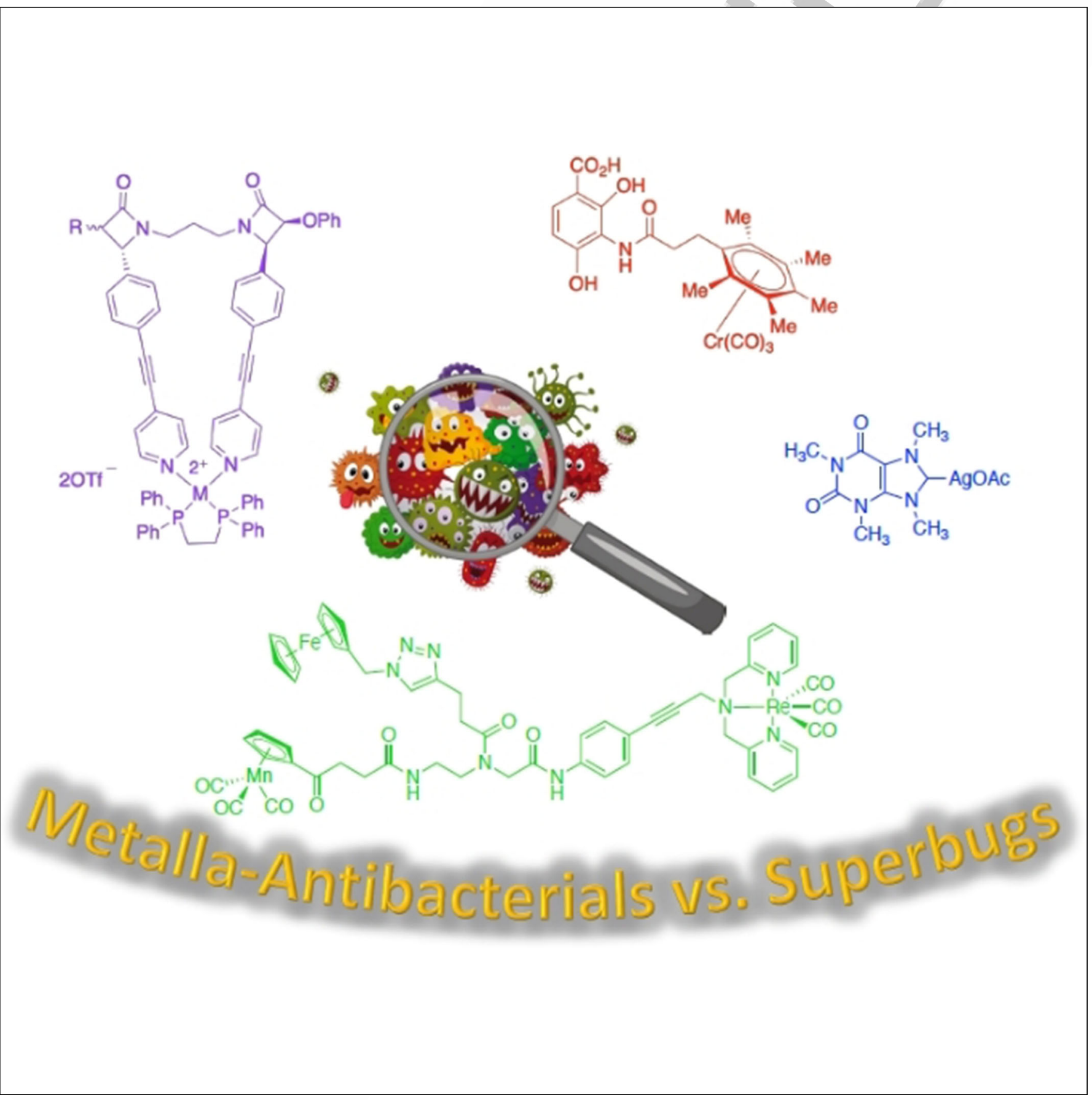


Abstract: Overuse and misuse of antibacterial drugs has resulted in bacteria resistance and in an increase in mortality rates due to bacterial infections. Therefore, there is an imperative necessity of new antibacterial drugs. Bio-organometallic derivatives of antibacterial agents offer an opportunity to discover new active antibacterial drugs. These compounds are well-characterized products and, in several examples, their antibacterial activities have been studied. Both inhibition of the antibacterial activity and strong increase in the antibiotic activity of the parent drug have been found. The synthesis of the main classes of bio-organometallic derivatives of these drugs, as well as examples of the use of structure-activity relation $\mathbf{D}$ Ok? (SAR) studies to increase the activity and to understand the mode of action of bio-organometallic antimicrobial peptides (BOAMPs) and platensimicyn bio-organometallic mimics is presented in this article.

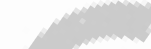

\section{Introduction}

Bacterial infections have always harassed humankind. Forensic archaeology has shown that, even before written history, the infection by these microorganisms caused disturbance, pain, and dead to our ancestors. From the beginning of our era to modern times, the scourge of pathogenic bacteria to humankind has provoked near extinction events in several zones of Earth. Epidemics like cholera, plague, and tuberculosis have steadily, suddenly and repeatedly punished mankind. Today, in spite of the enormous advances of modern medicine, bacterial infections claim around 1.5 million human lives yearly. ${ }^{[1]}$

The last century witnessed the appearance of an impressive arsenal of antibacterial drugs, to the point that, at the beginning of the second half of the twentieth century, it was thought that mankind was finally winning the eras long fighting against bacteria. ${ }^{[2]}$ Complementing the antibacterial agents isolated from natural sources, or produced by hemisynthesis, fully synthetic antibacterial agents were prepared in the laboratories. These synthetic compounds proved to be equally if not more efficient than their natural counterparts.

In spite of these facts, the evolutionary pressure derived from the indiscriminate use of antibacterial agents resulted, almost immediately, ${ }_{1}^{[3]}$ in the development of bacteria strains capable of resisting the action of the commonly used antibiotics (at that moment mainly penicillin and sulfa derivatives). Nowadays the preparation of novel antibacterial agents has a priority due to the apparition of pathogens with multidrug resistance. ${ }^{[2]}$ A discussion of the different strains of bacteria resistant to the antibacterial drugs is out of the scope of this arti-

[a] Prof. M. A. Sierra, Prof. L. Casarrubios

Departamento de Química Orgánica, Facultad de Química Universidad Complutense, 28040 Madrid (Spain)

E-mail: sierraor@ucm.es

[b] Dr. M. C. de la Torre

Consejo Superior de Investigaciones Científicas (CSIC)

Instituto de Química Orgánica General

Juan de la Cierva 3, 28006 Madrid (Spain)

[c] Prof. M. A. Sierra, Prof. L. Casarrubios, Dr. M. C. de la Torre Centro de Innovación en Química Avanzada (ORFEO-CINQA)

Facultad de Química, Universidad Complutense 28040 Madrid (Spain)

iD The ORCID identification number(s) for the author(s) of this article can be found under:

https://doi.org/10.1002/chem.201805985. cle, but, for example, and taking apart Mycobacterium tuberculosis (the organism causing tuberculosis that still raise havoc both in developed and underdeveloped countries), Staphylococcus aureus (resistant to methicillin, MRSA), Enterococcus faecium (resistant to vancomycin or fluoroquinolone), or/and resistant Pseudomonas aeruginosa are becoming more and more virulent and the lack of efficient treatments leads to high mortality rates. ${ }^{[1,4]}$

The poor response of pharmaceutical industry about producing new drugs to fight bacterial infections is causing serious concern among governmental institutions. For example, in 2015 the World Health Organization (WHO) approved a global plan to combat antibiotic resistance, and a recent review panel appointed by the UK government called for a $£ 1.3$ billion (US\$2 billion) investment from the global drug industry to revitalize antibiotic research..$^{[5]}$

Two main trends are followed in this field:

1. The discovery of new antibacterial agents able to keep their activity in the presence of resistant bacteria. These new drugs will be obtained both by chemical and biological synthesis.

2. The development of novel compounds to inactivate the mechanisms through which bacteria render useless the conventional antibacterial drugs allowing these drugs to exercise their action.

On both fronts, it is foreseeable that bio-organometallic derivatives of conventional antibacterial drugs, ${ }^{[6]}$ as well as new bio-organometallic compounds, ${ }^{[7]}$ will be an option to be taken into consideration. This article covers the synthesis of the different classes of bio-organometallic derivatives containing either the antibacterial drug, the active moiety of the drug, or using the metal to mimic a part of the drug that is synthetically hard to make. Examples of the use of structure-activity relation Ok? (SAR) studies to increase the activity and to understand the mode of action of bio-organometallic antimicrobial peptides (BOAMPs) and platensimicyn bio-organometallic mimics will also be presented. 


\section{Transition-metal coordination complexes and bio-organo- metallic derivatives of antibacterial drugs}

Transition-metal coordination complexes have been prepared from several classes of the clinically used drugs. Two different situations are found in the coordination chemistry of these compounds:

1. Coordination complexes of antibacterial agents with structures either not confirmed by X-ray diffraction or ill characterized. The coordination chemistry of $\beta$-lactam antibacterial agents is an example of this situation. Clinically used $\beta$ lactam antibacterial drugs are multidentated ligands and amphoteric systems. Therefore, the coordination of these substances to a metal is $\mathrm{pH}$ dependent. Additionally, the possibility of different metal/ligand stoichiometries results in a complicated coordination chemistry of $\beta$-lactam antibacterial agents. ${ }^{[8]}$

2. Well-characterized coordination complexes of antibacterial agents, including X-ray diffraction structure determination. The coordination chemistry of quinolone antibiotics exemplifies this situation. ${ }^{[9]}$

Frequently, the coordination complexes pertaining to these two classes of complexes have activities similar to those observed for the free ligands. Although this fact points to the liberation of the biologically active ligand, in some cases, inhibition of the antibacterial activity of the ligand by the presence of the metal has been observed.

The reported bio-organometallic derivatives of antibacterial agents have well-defined structures that can be established by standard spectroscopic, spectrometric, and X-ray diffraction techniques. Additionally, these compounds do not release the bio-active moiety, which causes notable differences in the activity with respect to the unmetallated drug. The ferrocene (Fc)-containing derivatives 1 and 2 prepared by acylation of 6aminopenicillanic (6-APA) and 7-aminocephalosporanic acids (7-ACA), respectively, are examples of bio-organometallic derivatives of commercially available $\beta$-lactam antibiotics (Scheme 1). ${ }^{[10]}$

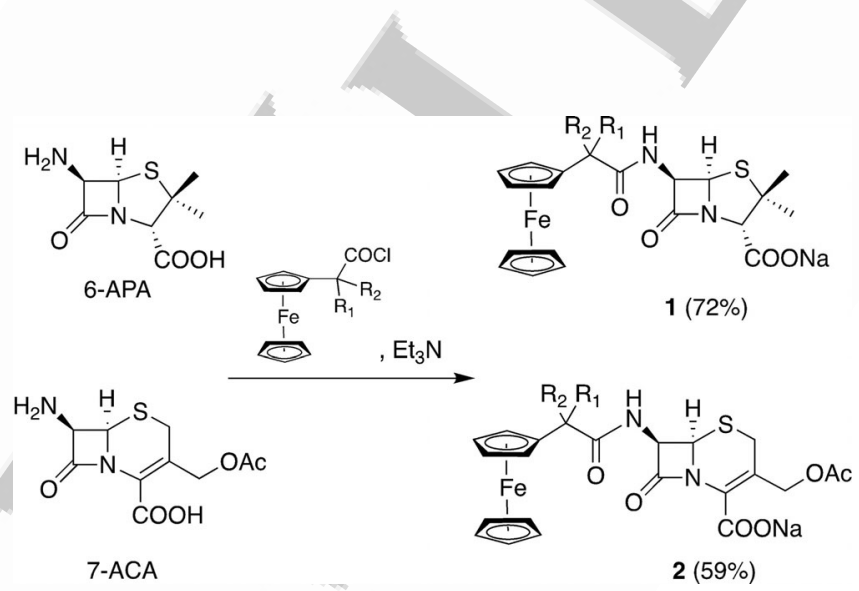

Scheme 1. Synthesis of 2-ferrocenylpropanoyl and 2-ferrocenyl-2-metylpropanoyl derivatives by acylation of 6-APA and 7-ACA, respectively.

\section{3. $\beta$-Lactam-derived bio-organometallic com- pounds}

The synthesis of $\beta$-lactam-derived bio-organometallic compounds has been profusely studied. Two different approaches have been used for the preparation of these classes of compounds:

1. Incorporation of the metallic moiety into a natural or a synthetic $\beta$-lactam derivative having a preformed 2 -azetidinone ring (Scheme $2 \mathrm{a}$ ).

Miguel A. Sierra obtained his Ph.D. in 1987 (UCM). After a post-doctoral stay in Colorado State University (1988-1989, Prof. L. S. Hegedus) he got a permanent position at the UCM (1990) as Associated Professor. He was promoted to full professor in 2005. Prof. Sierra was a member of the Scientific Advisory Board of the Organization for the Prohibition of Chemical Weapons (2003-2009). Actually he is the General Editor of Anales de Química, and a member of the Editorial Board of the European Journal of Organic Chemistry. He was awarded (2003) the Military Cross with white ribbon, and the Ignacio Ribas Excellence Award from the Organic Division of the Spanish Chemical Society (2013). Prof. Sierra research interest ranges focus in the synthesis of functional bio-organometallic compounds, the decontamination of chemical warfare agents, and the design and the synthesis of energetic materials.

Luís Casarrubios was born in Madrid, got his bachelor's degree in chemistry in 1991 (UCM) and his Ph.D. in 1995 (Cum laude and UCM Thesis award). After a post-doctoral stay at the University of North Carolina at Chapel Hill with Prof. M. Brookhart he joined the Universidad San Pablo CEU in Madrid as an assistant professor in 1997 where he worked until 2002. He then moved to the pharmaceutical industry for almost four years (Eli Lilly, Spain) and in January 2006 he returned to the university as a Ramon y Cajal. He got promoted to Associate Professor in 2008 and he is now a team leader of the Bio-organometallic chemistry group. His research along these years has been centered in multiple areas: Fischer complexes chemistry, catalysis, Pauson-Khand reaction, metathesis, medicinal chemistry, scale-up processes and is actually centered in bio-organometallic and computational chemistry.

María C. de la Torre studied chemistry at the Universidad Complutense de Madrid where she received her Ph.D. in 1986. After postdoctoral work at Imperial College (Steven Ley) and Colorado State University (Albert Meyers), she returned to Madrid in 1989 as a scientific researcher at the Consejo Superior de Investigaciones Cientificas (CSIC). At present she is senior researcher at the Instituto de Química Orgánica General (IQOG). Dr. de la Torre has been involved in the chemistry of natural products, the synthesis of natural product hybrids, and the development of new processes of chirality transfer in organometallic com-

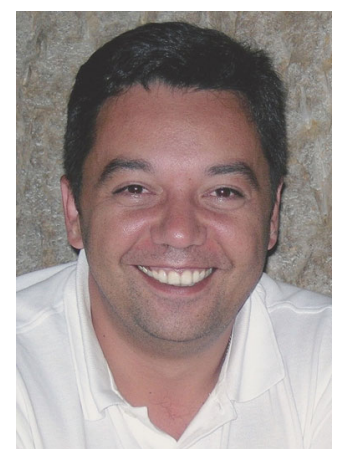
pounds.

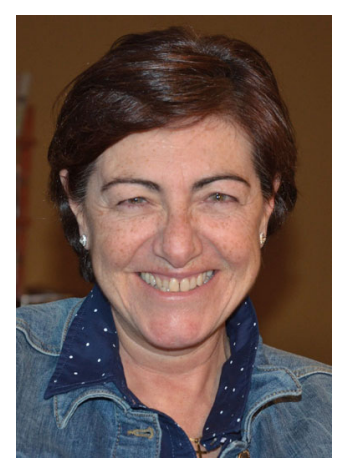

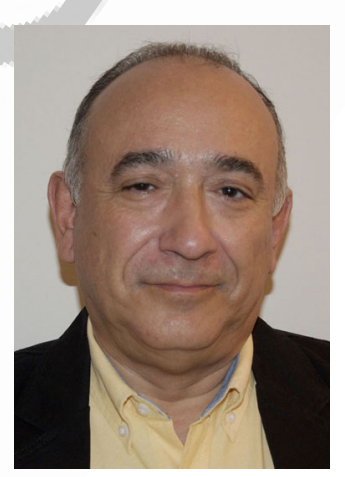


(a)

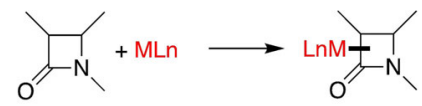

(b)

$$
\begin{aligned}
& \mathrm{LnM}-\mathrm{GF}_{1}+\mathrm{GF}_{2} \longrightarrow \\
& \mathrm{GF}_{1}=\text { enolate, ketene, nitrone }
\end{aligned}
$$$$
\text { OnM }
$$$$
\mathrm{GF}_{2}=\text { imine, alkyne }
$$

Scheme 2. Two alternative approaches to the building of the metalla-2-azetidinone ring. a) Incorporation of the metallic moiety into a $\beta$-lactam derivative having a preformed 2-azetidinone ring. b) Building the four-membered $\beta$-lactam ring with simultaneous incorporation of the metal complex.

2. Building the four-membered $\beta$-lactam ring with simultaneous incorporation of the metal complex. The metallic fragment is contributed by one of the reagents (Scheme $2 b$ ). This approach is more effective in terms of generation of structural diversity.

\subsection{Incorporation of the metal in a preformed $\beta$-lactam}

This approach has been mainly restricted to the formation of amide linkages (metallocene carboxamide or sulfonamide) by using the 6-amino group in 6-APA or 7-ACA derivatives. The first examples of incorporation of a ferrocene moiety to a penicillin or cephalosporin nucleus were reported by Edwards in 1975 (see above, Scheme 1). ${ }^{[10]}$ Other ferrocenylamide derivatives of penicillin and cephalosporins were prepared subsequently by these authors. ${ }^{[10 b]}$ The resulting compounds showed variable degrees of antibacterial activity. The closer the ferrocene moiety was to the four-membered ring the less active were the new derivatives. Penicillin and cephalosporines tethered through a ferrocene moiety were prepared by the reaction of 1,1'-ferrocenyldiacetic anhydride and 6-APA or 7-ACA, respectively. ${ }^{[11]}$

Following analogous procedures to those depicted in Scheme 1, several derivatives of 6-APA or 7-ACA were prepared by changing the nature of the ferrocene acylating moiety. ${ }^{[12]}$ The activity of these new ferrocene-containing antibiotic derivatives towards Gram-positive bacteria was similar, or slightly lower, than that of the control samples employed (amoxicillin, carbenicillin, and cephalothin). The activity towards Gram-negative bacteria was found to be insignificant.

More recently, the ruthenocene (Rc)-APA derivative 3 has been prepared by reaction of 6-APA with the ruthenocene derivative 4 . The complex of 3 with CTX-M $\beta$-lactamase has been analyzed by X-ray diffraction (Scheme 3). ${ }^{[13]}$

By condensation of ferrocene acetyl chloride with 2-azetidinones substituted by a residue of alanine at the C3-position several $\beta$-lactam-containing ferrocene peptides have been prepared and their conformational properties were studied. ${ }^{[14]}$

The macrocyclic bis- $\beta$-lactams 5 , containing embedded $\mathrm{Pd}$ and Pt square-planar centers, were synthesized by the stepwise building of a bis-azetidinone system, having both rings tethered by an aliphatic chain, and the lactam nitrogen atom substituted by the terminal pyridine moieties $6 .^{[15]}$ Reaction of

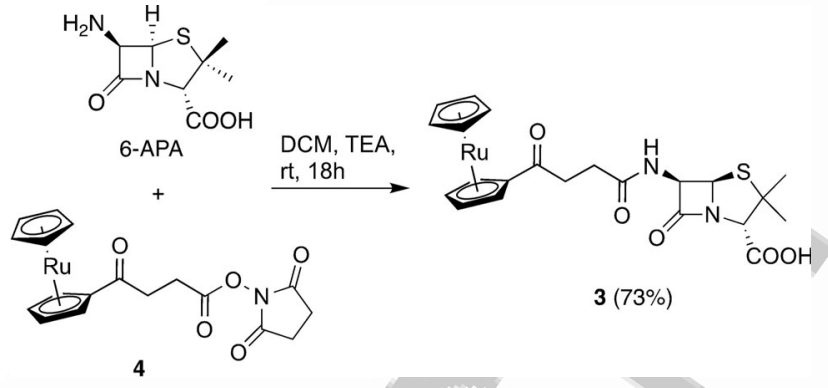

Scheme 3. Preparation of the 6-ruthenocene-APA derivative 3 (TEA = triethylamine).

compounds 6 with cis-[M(dppe) $\left.(\mathrm{OTf})_{2}\right](\mathrm{M}=\mathrm{Pd}, \mathrm{Pt}$, dppe $=1,2-$ bis(diphenyl-phosphino)ethane, $\mathrm{Tf}=$ triflate) in the presence of $\mathrm{NaOAc}$ formed the diastereomerically pure metallic cavities $\mathbf{5}$ in essentially quantitative yields (Scheme 4).

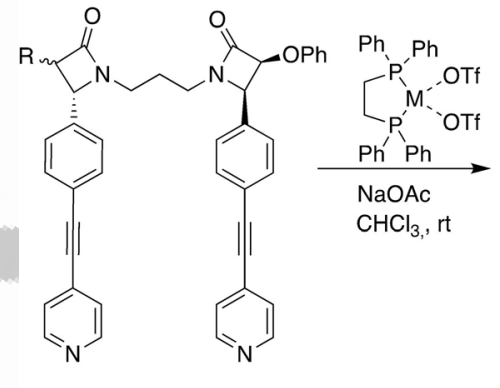

6

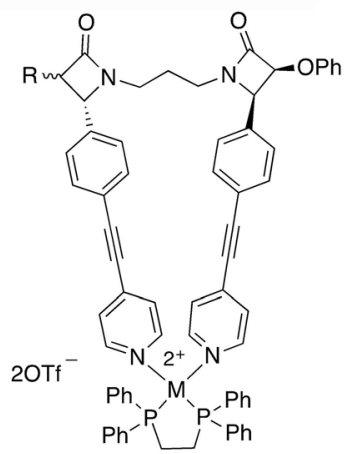

5 (95-98\%) $\mathrm{M}=\mathrm{Pd}, \mathrm{Pt}$ $\mathrm{R}=\alpha \mathrm{OPh}, \beta \mathrm{OPh}$

Scheme 4. Macrocyclic bis- $\beta$-lactams having embedded Pd and Pt squareplanar centers.

The $\mathrm{Cu}^{\prime}$-catalyzed alkyne-azide cycloaddition (CuAAC) ${ }^{[16]}$ was used in a related approach to macrocyclic bis- $\beta$-lactams. In these cases, the macrocycle was closed by using $\mathrm{N}$-alkyne-2azetidinones and diazides including 1, $1^{\prime}$-ferrocene-bis-azide. ${ }^{[17]}$

The introduction of the metal by $\mathrm{C}-\mathrm{H}$ bond activation in an adequately substituted $\beta$-lactam has been used to prepare metalla- $\beta$-lactams. ${ }^{[18]}$ Thus, 2 -azetidinones containing 2-phenylpyridyl substituents along the lactamic ring with the general formulae $\mathbf{7}$ were prepared by using a conventional Staudinger reaction between the corresponding imines and several acid chlorides. Reaction of compounds 7 with $\left[\mathrm{MCp}^{*} \mathrm{Cl}_{2}\right]_{2}(\mathrm{M}=\mathrm{Ir}, \mathrm{Rh}$, $C p^{*}=1,2,3,4,5$-pentamethylcyclopentadiene) in the presence of $\mathrm{NaOAc}$ yielded the corresponding $\beta$-lactams having the cyclometallated tethers $\mathbf{8}$. The yields were in all cases excellent and the final products were obtained as diastereomeric mixtures due to the newly formed chiral-at-metal center (Scheme 5).

A chelate-assisted $\mathrm{N}-\mathrm{H}$ bond activation of the 2-azetidinones 9 has been used to prepare the first series of metallatrinems 10 . These compounds are bio-organometallic analogues of the trinems (exemplified by sanfetrinem and 6-(1-hydroxyethyl)-cyclonocardicin, Scheme 6), ${ }^{[19]}$ in which the $\mathrm{N}-\mathrm{CH}$ 


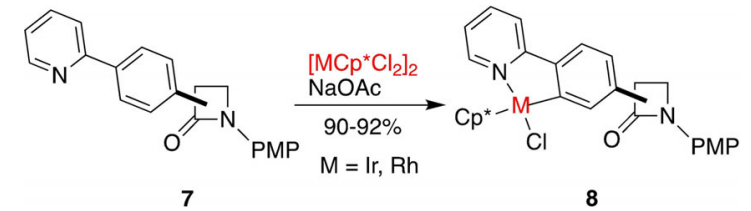

Scheme 5. Synthesis of metalla- $\beta$-lactam derivatives by $\mathrm{C}-\mathrm{H}$ bond activation.

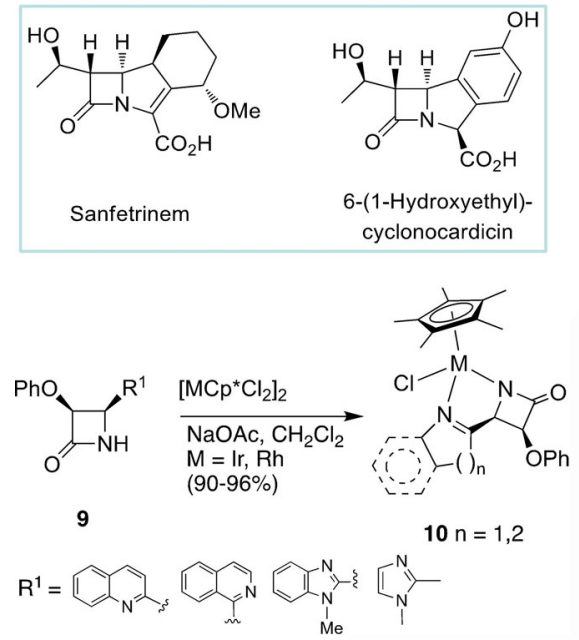

Scheme 6. Synthesis of metalla-trinems by $\mathrm{N}-\mathrm{H}$ bond activation.

group of the tricyclic system has been replaced by a metal (Ir, $\mathrm{Rh}, \mathrm{Os}$, or $\mathrm{Ru})^{\left[{ }^{[20]}\right.}$ Treatment of compounds 9 with $\left[\mathrm{MCp}^{*} \mathrm{Cl}_{2}\right]_{2}$ $(\mathrm{M}=\mathrm{Ir}, \mathrm{Rh})$ in the presence of $\mathrm{NaOAc}$ formed the metallatrinems 10 in high yields and acceptable diastereoselectivities (Scheme 6).

The method represented in Scheme 6 also allows the preparation of four-coordinated $d^{8}$ metal fragments (Ir, Rh). These compounds are excellent substrates to access molecular diversity by modification of the coordination sphere and the oxidation state of the metal center. Analogously, this approach is compatible with highly reducing metal complexes like $\mathrm{OsH}_{6}\left(\mathrm{PiPr}_{3}\right)_{2}{ }^{[20]}$

Other approaches to incorporate a metallic moiety to a preformed $\beta$-lactam ring have been reported. Thus, 2 -azetidinones having pentacarbonylchromium $(0)$ carbene moieties were prepared by aminolysis of pentacarbonylchromium(0)alkoxy carbenes. This methodology was used in the incorporation of the pentacarbonylmetal moiety into the 6-amino group, or the 1carboxylate group of penicillin G (PG). A simple modification of this approach allowed attaching the metallic complex to the carboxylic group of PG and cephalosporin. ${ }^{[21]}$

Finally, some $\beta$-lactam-alkyne- $\left[\mathrm{CO}_{2}(\mathrm{CO})_{6}\right]$ complexes have been characterized as intermediates in the synthesis of fused tricyclic $\beta$-lactam systems by using the Pauson-Khand reaction, ${ }^{[22]}$ and in processes of $\mathrm{N}$-depropargylation of $\mathrm{N}$-propargylsubstituted 2-azetidinones. ${ }^{[23]}$

\subsection{Procedures involving the construction of the $\beta$-lactam ring}

As indicated in Scheme 2, there are two main approaches to prepare metal-containing 2-azetidinones by building the fourmembered ring: the Staudinger reaction between a ketene precursor and an imine, ${ }^{[24]}$ and the enolate-imine cyclization. ${ }^{[25]}$

Thus, the synthesis of enantiopure trans-(+)-(3S,4S)-3-amino4-ferrocenyl-1- $p$-methoxyphenylazetidin-2-one (11) was made by reaction of the lithium enolate derived from the ester 12 and the ferrocenyl imine 13. The structure of $\mathbf{1 1}$ was determined by X-ray diffraction analysis (Scheme 7). ${ }^{[26]}$ Analogously,

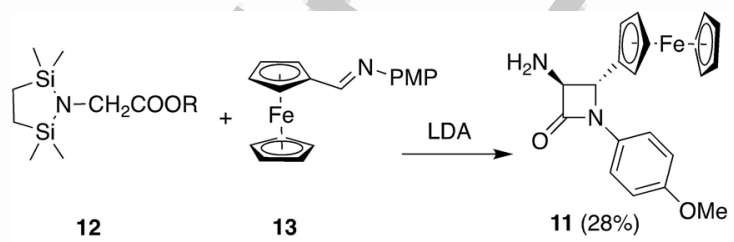

$\mathrm{R}=(1 S, 2 R, 5 S)-(+)-$ menthyl

$\mathrm{PMP}=p-\mathrm{MeOC}_{6} \mathrm{H}_{4}$

Scheme 7. Enolate-imine approach to metalla-2-azetidinones (LDA = lithium diisopropylamide).

several 4-ferrocenyl-substituted 2-azetidinones were prepared by using the reaction of ethylbromo acetate and ferrocenyl imines in the presence of indium under Barbier conditions. ${ }^{[27]}$ Further, the lithium enolate derived from ethyl ferrocenylacetate was reacted with different imines to form the corresponding 2-azetidinones having a ferrocenylmethylene substituent at the C3-position. ${ }^{[28]}$

The first synthesis of a $\beta$-lactam containing ferrocene substituents by using the Staudinger reaction was reported as early as 1978. Thus, the reaction of several ferrocenyl imines 14 with cloroacetyl chloride formed ferrocene-substituted 2azetidinones 15 (Scheme 8). The corresponding bis-2-azetidinones were obtained by using diimines derived from ferrocene carbaldehyde and diamines. ${ }^{[29 a]}$ Analogously, bis- $\beta$-lactams have been prepared from diimines derived from $1,1^{\prime}$-ferrocene dicarbaldehyde through a Staudinger reaction. Further manipulation of these compounds produced macrocycles having embedded bis- $\beta$-lactams. ${ }^{[29 b]}$

Several ferrocenyl- $\beta$-lactams having the ferrocene moiety attached to different positions of the four-membered ring were

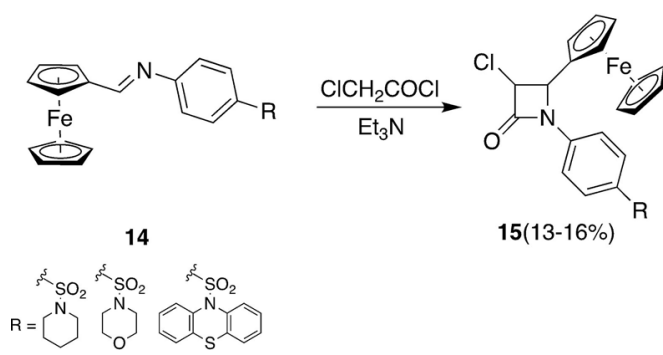

Scheme 8. Staudinger $[2+2]$ cycloaddition of ketenes and imines approach to metalla-2-azetidinones. 
prepared by the photochemical reaction of pentacarbonyl (ethoxymethyl)chromium( 0 ) carbene and different ferrocenyl imines. ${ }^{[28]} \mathrm{A}$ series of 2-azetidinones having a ferrocene moiety directly attached to the C3-position of the 2-azetidinone ring was prepared by the Staudinger reaction of ferrocenylacetic acid and several imines in the presence of $\mathrm{PhOP}(\mathrm{O}) \mathrm{Cl}_{2} \cdot{ }^{\left[{ }^{30]}\right.}$ Following a similar procedure cis-4-[( $\left(_{\mathrm{FC}}\right)-2-(p$-tolylsulfanyl)ferrocenyl]- $\beta$-lactams were synthesized in good yields by the onepot reaction of chiral-planar ferrocenylimines with substituted acetic acids. In these cases, the reaction was completely cis selective and a single enantiomer of the product was obtained..$^{[31]}$

The photochemistry of metallocene-substituted $\mathrm{Cr}^{0}$ Fischer carbene complexes produced several new structural types of metalla- $\beta$-lactams. Thus, the ruthenocene carbene complex 16 reacted with imines producing new types of the ruthenocenesubstituted mono- $\beta$-lactams 17 . The reaction of complex 16 with the chiral thiazoline $\mathbf{1 8}$ afforded the first example of the 6-ruthenocenyl-penicillin nucleus 19 (Scheme 9). ${ }^{[32]}$ It should be noted that, contrary to other examples reported above, compound 19 has the ruthenocene substituent joined directly to the penam nucleus.
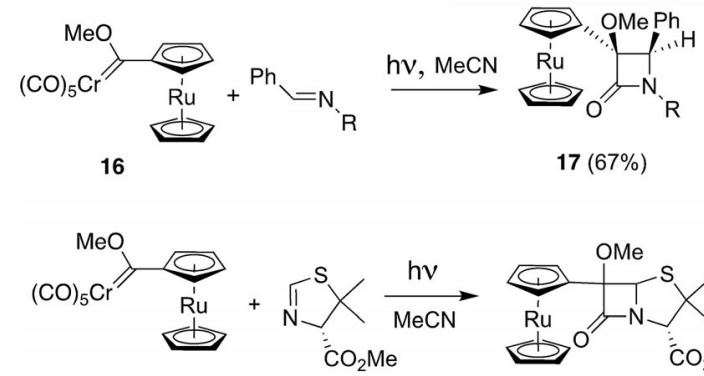

16

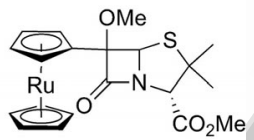

$19(46 \%)$
Scheme 9. Synthesis of ruthenocene- $\beta$-lactams

The Kinugasa reaction ${ }^{[33]}$ has been used to develop a general approach to the 3-metallocenyl-2-azetidinones 20 and the 3half-sandwich 2 -azetidinones $21 .^{[34]}$ The reaction used the alkynylmetallocenes $\mathbf{2 2}$ or the alkynyl-half-sandwich derivatives $\mathbf{2 3}$ to incorporate the metallic moiety during the building of the four-membered ring. Although the control of the cis/trans selectivity was low and the enantioselectivities poor, this approach is an easy entry to $\beta$-lactams having metal substituents at different positions of the four-membered ring (Scheme 10).

A four-component reaction involving an isocyanide, an amine, a carbonyl compound, and a carboxylic acid has been used to prepare the $\beta$-lactams 24 and the penam derivatives 25. Thus, reaction of the ferrocene isonitrile $\mathbf{2 6}$ with isobutyraldehyde and 3-aminopropionic acid formed the C3-unsubstituted 2-azetidinone $\mathbf{2 4}$ as a 3:1 mixture of diastereomers. The use of 2,5,5-trimethyl-2,5-dihydrothiazole-2-acetic acid (27) formed the penam derivative $\mathbf{2 5}$ as a complex diastereomeric mixture (Scheme 11)..$^{[35]}$

The reactions described above show the diversity of structures that are accessible by using simple synthetic procedures.

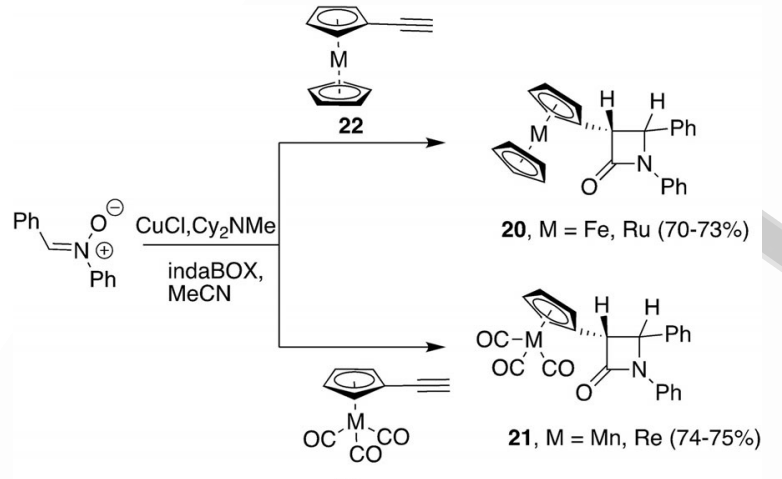

23

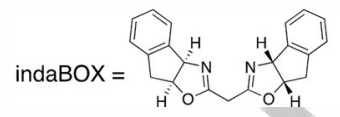

Scheme 10. Preparation of metalla-2-azetidinones by the Kinugasa reaction.

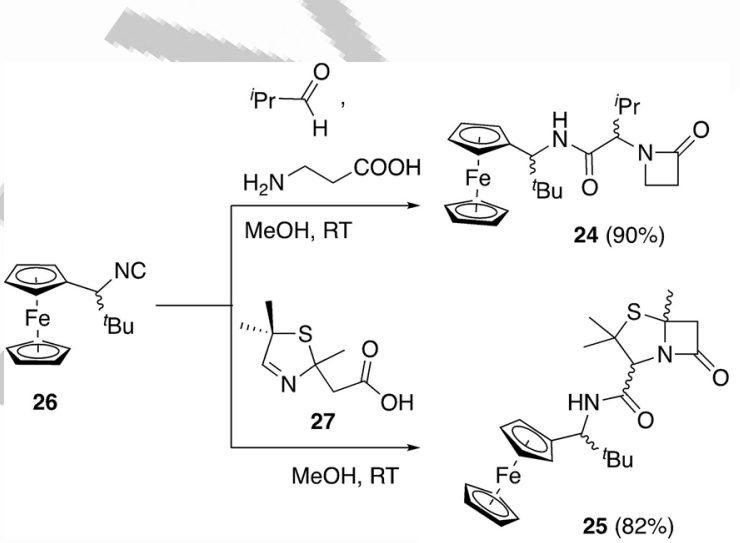

Scheme 11. Four-component approach to metalla-2-azetidinones.

Many of these compounds have been characterized by X-ray diffraction analysis. However, except in a few cases, the antibacterial activity of the reported compounds was not determined.

\section{Bio-organometallic Ag' antibacterial com- plexes}

Silver was one of the first antibacterial agents used by humanity. In fact, data suggest that silver was used to make potable water as early as 1000 years B.C. Herodotus, accounts that no Persian king, including Cirrus, would drink water that was not transported in silver containers, which kept the water fresh for years. ${ }^{[36]}$ Actually, silver sulfadiazine (28) (Figure 1) $)^{[37]}$ works as a broad-spectrum antibiotic used mainly in the treatment of burn wounds. Compound $\mathbf{2 8}$ acts as a reservoir of $\mathrm{Ag}^{\prime}$ in the wound liberating slowly these ions. The importance of silver-based new materials and coatings, as well as the use of silver nanoparticles as antibacterial agents is exponentially increasing and these topics have been thoroughly reviewed. $^{[38]}$

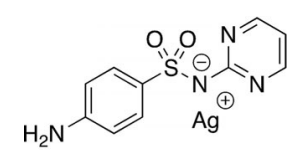

28

Figure 1. Silver sulfadiazine. 
The range of bio-targets of Agantibacterial agents is wide. In spite of the fact that cytotoxic effects of silver and silver complexes against both Gram-positive and Gram-negative bacteria are established, the mechanisms of action of these compounds are still not well understood. ${ }^{[39]}$ It is thought that the common mechanism of action of $\mathrm{Ag}$ antibacterial agents is through slow release of the active metal ion, which reacts with the thiol groups of proteins or with key functional groups of enzymes. The result of these interactions is the dysfunction of the protein structure and the impairing of the membrane function. ${ }^{[40]}$ Additionally, in the case of $E$. coli, silver ions produce reactive oxygen species (ROS) depleting antioxidant reserves in the bacteria. Moreover, upon treatment with silver, condensed DNA molecules have been observed in some cases in the bacteria cytoplasm. The condensed DNA inhibits their ability to replicate, which results in detriment of the survival of the bacteria. On the other hand, the antitumoral activity of $\mathrm{Ag}^{\prime}$ is directly related to its interaction with nucleic acids, ${ }^{[41]}$ which may point to an additional mechanism of activity against bacteria.

Strictly speaking the sole examples of bio-organometallic derivatives of silver are caffeine- $\mathrm{Ag}^{\prime}$ mixed $\mathrm{N}$-heterocyclic carbenes (NHCs). Complex 29 was prepared from methylated caffeine 30 and excess of $\mathrm{Ag}_{2} \mathrm{O}$ in $\mathrm{MeOH}$. By dissolving the complex 29 in EtOAc, the Ag NHC 31 was obtained (Scheme 12). This monocarbene could be directly obtained by reaction of 30 with silver acetate in $\mathrm{MeOH} .{ }^{[42]}$

$$
\text { (85\%) }
$$

Scheme 12. Antibacterial caffeine- $A g^{\prime}$ derivatives.

The Ag' NHC 31 was evaluated against a variety of test organisms with special emphasis on highly resistant opportunistic pathogens recovered, primarily, from the respiratory tract of patients with cystic fibrosis. Activities in the range of 1$6 \mu \mathrm{gL}^{-1}$ (minimum inhibitory concentration) were determined against several strains of Pseudomonas aeruginosa, Escherichia coli, and diverse strains of Burkholderia. Moreover, this compound and the parent methylated caffeine show very low genotoxicity, which is interesting for clinical use. ${ }^{[43]}$

Interestingly, the simple $\mathrm{Ag}^{\prime} \mathrm{NHC} \mathbf{3 2}$ shows some activity towards Gram-positive Bacillus subtilis but was inactive towards
Gram-negative Escherichia coli. The isolated ligand was inactive against both types of bacteria. The analogous $\mathrm{Au}^{\prime} \mathrm{NHC} 33$ shows a similar antibacterial profile (Figure 2). ${ }^{[44]}$

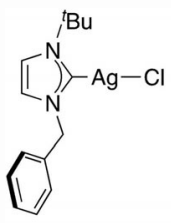

32

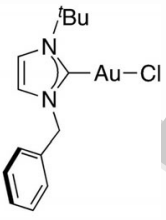

33
Figure 2. Two antibacterial $\mathrm{Ag}^{\prime}$ and $\mathrm{Au}^{\prime} \mathrm{NHC}$ complexes.

Several additional silver NHC complexes have been prepared. ${ }^{[45]}$ These complexes release $\mathrm{Ag}^{\prime}$ continuously over time, the substitution of the $\mathrm{NHC}$ ligand can be used to modulate the silver release, and, in principle, to control the systemic delivery of silver. ${ }^{[46]}$

\section{Bio-organometallic antibacterial metalla- peptides $^{[47]}$}

Antimicrobial peptides (AMPs) play diverse roles through nature, from their participation in the innate immunity of plants and invertebrates to the immunity of vertebrates, including humans. ${ }^{[4]}$ Similar to $\beta$-lactam antibiotics (which are conformationally constrained tripeptides, the $C$ terminus being the $\mathrm{COOH}$ group of the bicyclic system) AMPs target the bacterial cell membrane. The development of very active bio-organometallic antimicrobial peptides (BOAMPs) by the group of Metzler-Nolte represents a nice example of a detailed SAR study (see below). ${ }^{[47]}$

These compounds are prepared by joining of the organometallic moiety to a preformed peptide, usually before liberating this peptide from the solid phase of the peptide synthesizer. Thus, series of ferrocenyl- and cobaltocenium-containing peptides $\mathbf{3 4}$ were prepared from the corresponding peptides $\mathbf{3 5}$ attached to Rink amide resin by condensation with ferrocene carboxylic acid or cobaltocene carboxylic acid, respectively, and subsequent cleavage from the resin and deprotection of the side-chain protecting groups (Scheme 13). ${ }^{[49]}$ An enhanced antibacterial activity was observed for these metalla peptides compared to the non-metallated species. Following analogous

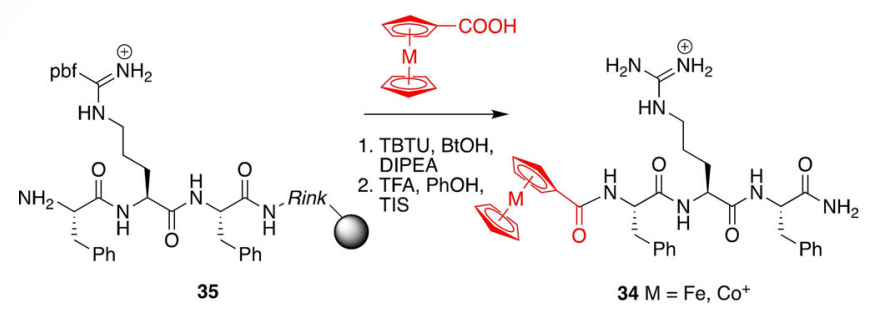

Scheme 13. Incorporation of the metal moiety during the synthesis of antibacterial ferrocenyl- and cobaltocenium-containing peptides (TBTU $=2-(1 \mathrm{H}$ benzotriazole-1-yl)-1,1,3,3-tetramethylaminium tetrafluoroborate, DIPEA $=$ diisopropylethylamine, TFA = trifluoroacetic acid, TIS $=\mathbf{\square} \mathbf{\square}$ Please define $\mathbf{\square}$ 
procedures, several peptides containing ferrocene, ${ }^{[50]}$ cobaltocene, ${ }^{[49,50]}$ and ruthenocene ${ }^{[51]}$ have been prepared.

Organometallic SAR studies were undertaken to optimize the antibacterial activity of BOAMPs. It was determined that peptides having the hydrophobic ferrocene moiety were, in general, more active against strains of Escherichia coli, Pseudomonas aeruginosa, and Staphylococcus aureus than the isostructural peptides having a cobaltocenium charged moiety. ${ }^{[49,50]}$ The hydrophobicity of ferrocene was claimed to be responsible for the increased antibacterial activity of these derivatives. ${ }^{[50]}$ It should be pointed out that metallocene derivatives of AMPs were stable in aqueous solutions. Therefore, leakage of the metal ion from the organometallic fragment is not likely to be the source of the antibacterial activity.

As matter evolves, ruthenocenyl derivatives were the most active compounds prepared. ${ }^{[51,52]}$ The change of L-amino acids to $\mathrm{D}$-amino acids in Mc-BOAMPs ( $\mathrm{Mc}=\mathrm{Fc}, \mathrm{Rc})$ also resulted in an increase of the antibacterial activity. Thus, a L-to-D scan of five of the seven amino acids of McCO-WRWRWW- $\mathrm{NH}_{2}$ formed four diasteromers having MIC of 0.7-1.5 $\mu \mathrm{M}$ against MRSAs (for comparison vancomycin and gramicidin have minimum inhibitory concentration (MIC) values of 0.6 and $2.8 \mu \mathrm{M}$, respectively, against the same MRSA strains). ${ }^{[3,54]}$

Multimetal BOAMPs were as well studied. Thus, the trimetal-

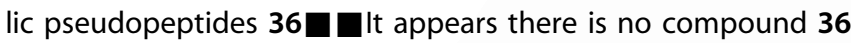
in Scheme 14, but two compounds named 39. Please check.

having a Fc or Rc, Re and Mn-PNA structure (PNA = peptide nucleic acid backbone) were prepared in a sequential CuAAC 口Ok? ם, amide bond formation, and Sonogashira coupling reaction (Scheme 14). ${ }^{[55]}$ Thus, the alkyne 37 was reacted with the azides $\mathbf{3 8}$ to form the monometallic triazoles 39 . Condensation with $p$-bromoaniline formed $\mathbf{4 0}$ that after deprotection of the amine group and 0 -(7-azabenzotriazol-1-yl)-tetramethyluronium hexafluorophosphate (HATU)-mediated coupling with 3-cymantrenylpropanoic acid formed the bimetallic species $\mathbf{4 1}$. The trimetallic species $\mathbf{3 6}$ were finally obtained by Sonogashira coupling with the Re pincer 42. Compound 36 shows a potent antibacterial activity against Staphylococcus aureus including MRSA and vancomycin-intermediate $S$. aureus 口Ok? (VISA) (low micromolar range), which compares to the activities of antibacterial drugs currently used in clinic. ${ }^{[5]}$ The study of the antibacterial properties of $\mathbf{3 6}$ is the first example of a metal-based antibacterial compound addressing both the antibacterial activity and the antibacterial target.

Subsequently, ${ }^{[57]}$ it was demonstrated that the trimetallic structure of $\mathbf{3 6}$ was not essential for the antibacterial activity of these BOAMPs. In fact, the $\left[(\mathrm{dpa}) \operatorname{Re}(\mathrm{CO})_{3}\right](\mathrm{dpa}=\mathrm{di}-(2-$ pyridyI)amide) fragment (marked in red in Scheme 14) is the crucial motif for the high activity of these compounds against Grampositive bacteria, including MRSA strains. It was postulated that, although all these BOAMPs target the bacteria membrane, the bi- and monometallic derivatives are more efficient in the membrane permeabilization. The scarce toxicity of these compounds toward mammalian cells, which makes then excellent candidates for further development as new antibacterial compounds, should be highlighted.

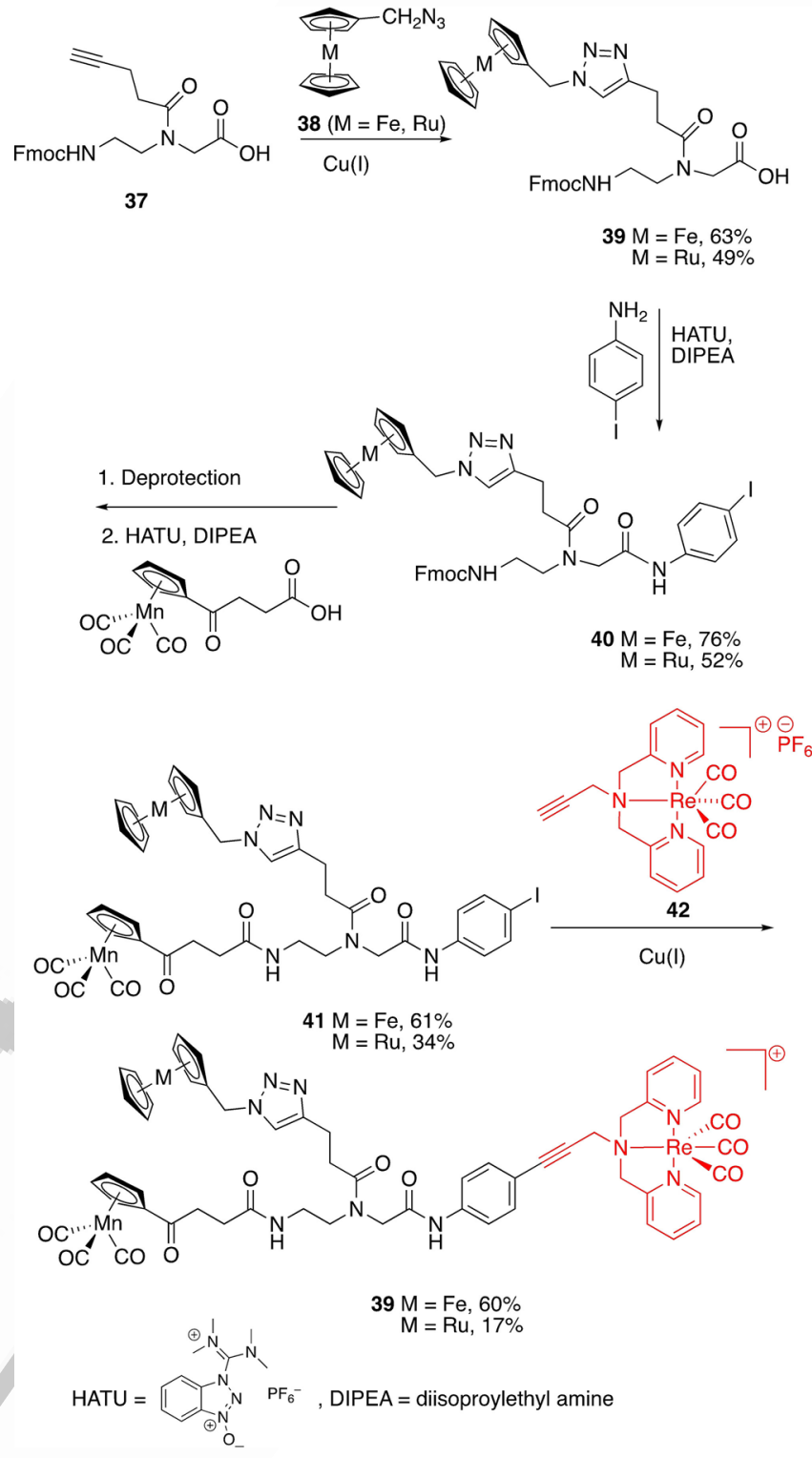

Scheme 14. Structures of Mc-PNA $(\mathrm{Mc}=\mathrm{Fe}, \mathrm{Ru})$ hetero tri-organometallic compounds. The crucial motif for the high antibacterial activity of these compounds is shown in red ( $\mathrm{Fmoc}=9$-fluorenylmethoxycarbonyl).

The development of BOAMPs by using SAR methods and the studies of their mode of action are clever examples of how methods of medicinal chemistry can be applied to the development of new bio-organometallic antibacterial agents.

\section{Bio-organometallic mimics of platensimycin}

Platensimycin (43) was isolated in 2006 by the Merck group from Streptomyces platensis. ${ }^{[58]}$ From the beginning the efficiency of this new antibacterial agent in the treatment of MRSA and vancomycin-resistant Enterococcus faecalis was recognized. This fact coupled to its novel mode of action (selective inhibition of the FabF enzyme in the bacterial fatty acid biosynthesis) and its low in vivo efficiency launched an extensive research program to improve the efficiency of this novel antibacterial agent. 
An interesting approach simplifies the platensimycin molecule by replacing the complex tetracylic moiety of the natural product by an $\eta^{6}$-benzene- $C r^{0}$-tricarbonyl fragment. The subjacent idea was to involve the three $\mathrm{CO}$ ligands in hydrogen bonds with amino acid residues in the active site of the FabF enzyme, like the two oxygen atoms of the tetracyclic moiety of platensimicyn, while keeping the bulkiness of the tetracyclic fragment. Manual docking experiments confirm that the bioorganometallic derivative fixed well into the active site of the enzyme, interacting through hydrogen bonding with the CO. Interestingly, the amino acid residues of the enzyme were different from the ones interacting with the natural antibiotic. ${ }^{[59]}$

The synthesis of these bio-organometallic platensimicyn mimics $\mathbf{4 4}$ uses the condensation of arenetricarbonyl acid derivatives and aromatic amines. Thus, for example, acid $\mathbf{4 5}$ was condensed with the amine $46\left(\mathrm{HATU} / \mathrm{Et}_{3} \mathrm{~N}\right)$ to form the platensimycin mimic 47 (Scheme 15). The antibacterial activity of these compounds was moderate. Several additional half-sandwich products ( $\mathrm{Cr}$ and $\mathrm{Mn}$ derivatives) related to $47,{ }^{[60 a]}$ including planar-chiral mimics ${ }^{[60 b]}$ were prepared. These compounds showed no antibacterial activity.

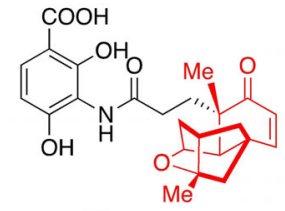

43<smiles>Cc1c(C)c(C)c(C(C)C)c(CCC(=O)O)c1C</smiles><smiles>COC(=O)c1ccc(OC)c(N)c1OC</smiles>

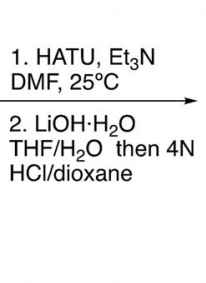

46

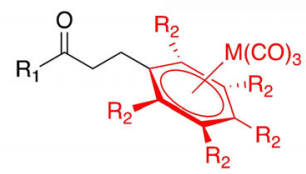

$$
44
$$

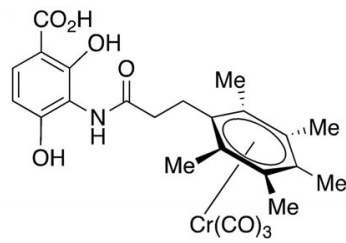

$47(45 \%)$

Scheme 15. Synthesis of platensimycin mimics.

In parallel, the ferrocene-containing platensimycin mimics 48 were prepared by condensation of the ferrocene-containing carboxylic acids 49 and the amine 46 , under the conditions depicted in Scheme 15 $\square 16$ ? $\square$. Compound 48 exhibits a low activity $\left(128 \mu \mathrm{g} \mathrm{mL}^{-1}\right)$ against Staphylococcus aureus Mu50 (VISA). The remaining compounds were inactive. ${ }^{[60 a, 61]}$ Enantiopure derivatives analogous to $\mathbf{4 8}$ were also inactive. ${ }^{[62]}$

The examples described above represent a nice sequence in the use of an organometallic moiety as a bioisostere of a structurally complex moiety of an antibacterial natural product. ${ }^{[63]}$ It has been proposed that the lack of activity of the above-given platensimycin mimics is due to the bulky ferrocene group that hampers the transmembrane mobility. ${ }^{[60 b]}$ However, the infor-<smiles>[R]c1ccccc1C(=O)CCCC(=O)O</smiles>

$$
49 \begin{array}{ll}
\mathrm{R}=\mathrm{COMe}, \mathrm{H} & \text { 1) } \mathrm{HATU}, \mathrm{DIPEA}, \\
{/ \mathrm{CH}_{3} \mathrm{CN}} }
\end{array}
$$

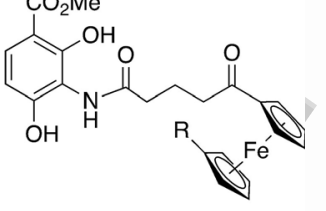

$48 \mathrm{R}=\mathrm{COMe}(39 \%)$ $\mathrm{R}=\mathrm{H}(62 \%)$

Scheme 16. Synthesis of ferrocene-based platensimycin mimics.

mation obtained from these studies is interesting, both in the way to obtain new antibacterial agents and as a proof of concept.

\section{Conclusion and Outlook}

The discussion above shows that the bio-organometallic chemistry of antibacterial agents is still underdeveloped. The appealing results obtained with multimetal antibacterial peptides clearly show the enormous potential of this field. However, except for BAL-30072 (Figure 3), which is a siderophore cur-

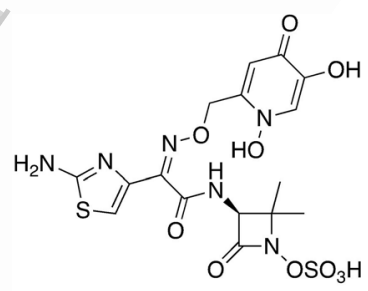

BAL-30072

Figure 3. Structure of BAL-30072.

rently under clinical development ${ }^{[64,65]}$ and taking apart silver preparations, the development of clinically relevant metal-containing antibiotics is still in its infancy. SAR studies have been used in different cases to obtain more active bio-organometallic antibacterial agents, as well as to understand their mode of action demonstrating the possibility of applying "organic" medicinal chemistry techniques to bio-organometallic derivatives. ${ }^{[66]}$

Overall, bio-organometallic compounds offer a paramount opportunity to find new antibacterial agents. The possibilities to introduce molecular diversity ${ }^{[67]}$ into a basic scaffold are clearly superior to the ones found in "classical" all-carbon structures. Additionally, several bio-organometallic compounds have modes of action different from the current antibacterial agents.

To achieve the final goal of using a bio-organometallic derivative as an antibiotic drug, the metal should be cheap and, evidently, non-toxic. Fortunately, several metals and their organometallic complexes fulfill these requisites. Unfortunately, 
pharma industry is not betting in the development of these new potential antibacterial agents, even knowing that bacteria resistance is rendering the current antibiotics inactive.

\section{Acknowledgements}

Support for this work under grants CTQ2016-77555-C2-1-R to M.A.S., CTQ2016-77555-C2-2-R to MCT and CTQ2016-81797REDC Programa Redes Consolider, from the MINECO (Spain) is gratefully acknowledged. M.A.S. thanks the Fundación Ramón Areces for a grant from the XVIII Concurso Nacional de Ayudas a la Investigación en Ciencias de la Vida y de la Materia.

\section{Conflict of interest}

The authors declare no conflict of interest.

Keywords: antibiotics - bio-organometallic antibacterial peptides - lactams - metallacycles - platensimycin mimics silver

[1] a) Review on Antimicrobial Resistance (Antimicrobial Resistance: Tack ling a crisis for the health and wealth of nations) presented to the UK Primer Minister in December 2014. https://amr-review.org/sites/default/ files/AMR\%20Review\%20Paper\%20-\%20Tackling\%20a\%20crisis\%20for\%20the\%20health\%20and\%20wealth\%20of\%20nations_1.pdf. The current estimations in this report are 10000000 dead worldwide due to AMR in 2050; b) European Centre for Disease prevention and Contro $(E C D C)$, European Medicine Agency (EMEA). The bacterial challenge: time to react (ECDC, 2009).

[2] Among the plethora of articles and books in this field, the monographic issue dedicated to bacterial resistance published in a) Chem. Rev. 2005, $105,391-774$, issue 2 , contains a discussion of the main clinically used antibacterial drugs, their mode of actions and the problems derived from the apparition of bacteria resistant to each class of antibiotics. See, also b) Nat. Rev. Microbiol. 2010, 8, 836 (Editorial of the monographic issue).

[3] The first $\beta$-lactamase was identified in the early 1940s prior to the large-scale use of penicillin. a) E. Abraham, BioEssays 1990, 12, 601; b) R. J. Anderson, P. W. Groundwater, A. Todd, A. Worsley, Antibacterial Agents: Chemistry, Mode of Action, Mechanisms of Resistance and Clinical Applications, Wiley, New York, 2012.

[4] H. W. Boucher, G. H. Talbot, J. S. Bradley, J. E. Edwards, D. Gilbert, L. B. Rice, M. Scheld, B. Spellberg, J. Bartlett, Clin. Infect. Dis. 2009, 48, 1.

[5] a) WHO Global Plan on antimicrobial resistance, http://www.wpro.who.int/entity/drug_resistance/resources/global_action_plan_eng.pdf (accessed on October 31, 2018). b) C. Lok, Nature 2015, 522, 270-273.

[6] For a perspective on small organometallic compounds as antibacterial agents, see: M. Patra, G. Gasser, N. Metzler-Nolte, Dalton Trans. 2012, 41, 6350-6358.

[7] Bio-organometallic compounds are "those biologically active compounds having at least one $\mathrm{M}-\mathrm{C}$ bond". See, among others: a) Bioorganometallic Chemistry Applications in Drug Discovery, Biocatalysis, and Imaging (Eds.: G. Jaouen, M. Salmain), Wiley-VCH, Weinheim, 2015; b) Bioorganometallics (Ed.: G. Jaouen), Wiley-VCH, Weinheim, 2006.

[8] For a comprehensive revision of the coordination chemistry of penicillins and cephalosporins, see: V. G. Alekseev, Pharm. Chem. J. 2012, 45, 679-697, (Russian original: V. G. Alekseev $\mathbf{\square}$ Ok? $\mathbf{\square}$, Khim.-Farm. Zh. 2011, 45, 31).

[9] Selected reviews on quinolone-metal complexes, a) I. Turel, Coord. Chem. Rev. 2002, 232, 27-47; b) A. Serafin, A. Stanczak, Russ. J. Coord. Chem. 2009, 35, 81-95; c) G. Psomas, D. P. Kessissoglou, Dalton Trans. 2013, 42, 6252-6276.
[10] a) E. I. Edwards, R. Epton, G. Marr, J. Organomet. Chem. 1975, 85, C23C25; b) E. I. Edwards, R. Epton, G. Marr, J. Organomet. Chem. 1976, 107, $351-357$.

[11] E. I. Edwards, R. Epton, G. Marr, J. Organomet. Chem. 1976, 122, C49C53.

[12] a) D. Scutaru, I. Mazilu, M. Vata, L. Tataru, A. Vlase, T. Lixandru, Cr. Simionescu, J. Organomet. Chem. 1991, 401, 87-90; b) D. Scutaru, L. Tataru, I. Mazilu, E. Diaconu, T. Lixandru, C. Simionescu, J. Organomet. Chem 1991, 401, $81-85$; c) D. Scutaru, L. Tataru, I. Mazilu, M. Vata, T. Lixandru, C. Simionescu, Appl. Organomet. Chem. 1993, 7, 225-231; d) C. Simionescu, T. Lixandru, D. Scutaru, M. Vata, J. Organomet. Chem. 1985, 292, 269-273.

[13] E. M. Lewandowski, J. Skiba, N. J. Torelli, A. Rajnisz, J. Solecka, K. Kowalski, Y. Chen, Chem. Commun. 2015, 51, 6186-6189.

[14] V. Kovac, K. Radolovic, I. Habus, D. Siebler, K. Heinze, V. Rapic, Eur. J. Inorg. Chem. 2009, 389-399.

[15] D. Pellico, M. Gómez-Gallego, P. Ramírez-López, M. J. Mancheño, M. A. Sierra, M. R. Torres, Chem. Eur. J. 2009, 15, 6940-6952.

[16] M. Meldal, C. W. Tornøe, Chem. Rev. 2008, 108, 2952-3015.

[17] D. Pellico, M. Gómez-Gallego, P. Ramírez-López, M. J. Mancheño, M. A Sierra, M. R. Torres, Chem. Eur. J. 2010, 16, 1592-1600.

[18] J. G. Muntaner, L. Casarrubios, M. A. Sierra, Org. Biomol. Chem. 2014, 12, $286-297$

[19] Targets in Heterocyclic Systems: Chemistry and Properties (Eds.: O. Attanasi, D. Spinelli), Italian Chemical Society, Rom, 1997.

[20] a) L. Casarrubios, M. A. Esteruelas, C. Larramona, J. G. Muntaner, M. Oliván, E. Oñate, M. A. Sierra, Organometallics 2014, 33, 1820-1833; b) L. Casarrubios, M. A. Esteruelas, C. Larramona, A. Lledós, J. G. Muntaner, E. Oñate, M. A. Ortuño, M. A. Sierra, Chem. Eur. J. 2015, 21, 16781 16785.

[21] M. A. Sierra, M. Rodríguez-Fernández, L. Casarrubios, M. Gómez-Gallego, M. J. Mancheño, Eur. J. Org. Chem. 2009, 2998-3005.

[22] B. Alcaide, C. Polanco, M. A. Sierra, J. Org. Chem. 1998, 63, 6786-6796.

[23] B. Alcaide, J. Pérez-Castells, B. Sánchez-Vigo, M. A. Sierra, J. Chem. Soc. Chem. Commun. 1994, 587-588.

[24] a) "Stereocontrolled ketene-imine cycloaddition reactions": G. I. Georg, V. T. Ravikumar in The Organic Chemistry of $\beta$-Lactams (Ed.: G. I. Georg), VCH, Weinheim, 1992, pp. 295-368; b) G. S. Singh, Tetrahedron 2003, 59, 7631-7649; c) T. T. Tidwell, Ketenes II, Wiley, New York, 2006, pp. 500-513; d) F. P. Cossío, A. Arrieta, M. A. Sierra, Acc. Chem. Res. 2008, 41, 925-936.

[25] D. J. Hart, D.-C. Ha, Chem. Rev. 1989, 89, 1447-1465.

[26] T. Poljak, K. Molcanov, A. Visnjevac, I. Habus, V. Kovac, V. Rapic, J. Mol. Struct. 2005, 751, 60-64.

[27] A. Ghatak, F. F. Becker, B. K. Banik, Heterocycles 2000, 53, 2769-2773.

[28] M. A. Sierra, M. J. Mancheño, R. Vicente, M. Gómez-Gallego, J. Org. Chem. 2001, 66, 8920-8925.

[29] a) K. M. Hassan, Z. Naturforsch. B 1978, 33, 1508-1514; b) M. A. Sierra M. Rodríguez-Fernández, L. Casarrubios, M. Gómez-Gallego, C. P. Allen, M. J. Mancheño, Dalton Trans. 2009, 8399-8405.

[30] B. F. Bonini, C. Femoni, M. Comes-Franchini, M. Fochi, G. Mazzanti, A. Ricci, G. Varchi, Synlett 2001, $1092-1096$.

[31] L. Bernardi, B. F. Bonini, M. Comes-Franchini, G. Dessole, M. Fochi, A. Ricci, Eur. J. Org. Chem. 2005, 3326-3333.

[32] M. L. Lage, I. Fernández, M. J. Mancheño, M. Gómez-Gallego, M. A. Sierra, Chem. Eur. J. 2009, 15, 593-596.

[33] a) M. Kinugasa, S. Hashimoto, J. Chem. Soc. Chem. Commun. 1972, 466 467; b) B. Mandal, B. Basu, Top. Heterocycl. Chem. 2012, 30, 85; c) J. Marco-Contelles, Angew. Chem. Int. Ed. 2004, 43, 2198-2220; Angew. Chem. 2004, 116, 2248-2250.

[34] B. Baeza, L. Casarrubios, M. A. Sierra, Chem. Eur. J. 2013, 19, 11536 11540.

[35] Y.-Y. Tong, J. J. R. F. da Silva, A. J. L. Pombeiro, G. Wagner, R. Herrmann, J. Organomet. Chem. 1998, 552, 17-21.

[36] a) J. W. Alexander, Surg. Infect. 2009, 10, 289-292; b) H. J. Klasen, Burns 2000, 26, 131-138.

[37] N. C. Baenziger, A. W. Struss, Inorg. Chem. 1976, 15, 1807-1809.

[38] a) See the compilation of commercial preparations and drugs containing transition metals in the Supporting Information of J. A. Lemire, J. J. Harrison, R. J. Turner, Nat. Rev. Microbiol. 2013, 11, 371 -384. For selected reviews, see: b) M. Rai, A. Yadav, A. Gade, Biotechnol. Adv. 2009, 27, 
76-83; c) S. Ahmad, A. A. Isab, S. Ali, A. R. Al-Arfaj, Polyhedron 2006, 25, $1633-1645$; d) P. Pallavicini, G. Dacarro, Y. A. Diaz-Fernandez, A. Taglietti, Coord. Chem. Rev. 2014, 275, 37-53; e) G. Franci, A. Falanga, S. Galdiero, L. Palomba, M. Rai, G. Morelli, M. Galdiero, Molecules 2015, 20, 88568874.

[39] H. J. Klasen, Burns 2000, 26, 117-130.

[40] a) C. N. Banti, S. K. Hadjikakou, Metallomics 2013, 5, 569-596; b) L. Kyros, C. N. Banti, N. Kourkoumelis, M. Kubicki, I. Sainis, S. K. Hadjikakou, J. Biol. Inorg. Chem. 2014, 19, 449-464; c) M. Napoli, C. Saturnino, E. I. Cianciulli, M. Varcamonti, A. Zanfardino, G. Tommonaro, P. Longo, J. Organomet. Chem. 2013, 725, 46-53.

[41] Q. L. Feng, J. Wu, G. Q. Chen, F. Z. Cui, T. N. Kim, J. O. Kim, J. Biomed. Mater. Res. 2000, 52, 662-668.

[42] A. Kascatan-Nebioglu, A. Melaiye, K. Hindi, S. Durmus, M. J. Panzner, L. A. Hogue, R. J. Mallett, C. E. Hovis, M. Coughenour, S. D. Crosby, A. Milsted, D. L. Ely, C. A. Tessier, C. L. Cannon, W. J. Youngs, J. Med. Chem. 2006, 49, 6811-6818.

[43] A. Kascatan-Nebioglu, M. J. Panzner, C. A. Tessier, C. L. Cannon, W. J. Youngs, Coord. Chem. Rev. 2007, 251, 884-895.

[44] S. Ray, R. Mohan, J. K. Singh, M. K. Samantaray, M. B. Shaikh, D. Panda, P. Ghosh, J. Am. Chem. Soc. 2007, 129, 15042-15043.

[45] Reviews in the medicinal applications of imidazolium carbene-metal complexes, see: a) K. M. Hindi, M. J. Panzner, C. A. Tessier, C. L. Cannon, W. J. Youngs, Chem. Rev. 2009, 109, 3859-3884; b) Silver NHCs: X. Liang, S. Luan, Z. Yin, M. He, C. He, L. Yin, Y. Zou, Z. Yuan, L. Li, X. Song, C. Lv, W. Zhang, Eur. J. Med. Chem. 2018, 157, 62-80.

[46] K. M. Hindi, T. J. Siciliano, S. Durmus, M. J. Panzner, D. A. Medvetz, D. V. Reddy, L. A. Hogue, C. E. Hovis, J. K. Hilliard, R. J. Mallet, C. A. Tessier, C. L. Cannon, W. J. Youngs, J. Med. Chem. 2008, 51, 1577-1583.

[47] For a recent and comprehensive review on the synthesis and medicinal applications of organometallic-peptide bioconjugates, see: B. Albada, N. Metzler-Nolte, Chem. Rev. 2016, 116, 11797-11839.

[48] a) Peptide Antibiotics, Discovery, Modes of Action, and Applications (Eds.: C. J. Dutton, M. A. Haxell, H. A. I. McArthur, R. G. Wax), Marcel Dekker, New York, 2002; b) C. Chatterjee, M. Paul, L. Xie, W. A. van der Donk Chem. Rev. 2005, 105, 633-684; c) M. C. Bagley, J. W. Dale, E. A. Merritt, X. Xiong, Chem. Rev. 2005, 105, 685-714; d) M. Wenzel, A. I. Chiriac, A Otto, D. Zweytick, C. May, C. Schumacher, R. Gust, H. B. Albada, M. Penkova, U. Krämer, R. Erdmann, N. Metzler-Nolte, S. K. Straus, E. Bremer, D. Becher, H. Brötz-Oesterhelt, H.-G. Sahl, J. E. Bandow, Proc. Natl. Acad. Sci. USA 2014, 111, E1409-E1418.

[49] J. T. Chantson, M. V. V. Falzacappa, S. Crovella, N. Metzler-Nolte, J. Organomet. Chem. 2005, 690, 4564-4572.

[50] J. T. Chantson, M. V. V. Falzacappa, S. Crovella, N. Metzler-Nolte, ChemMedChem 2006, 1, 1268-1274.

[51] H. B. Albada, A.-I. Chiriac, M. Wenzel, M. Penkova, J. E. Bandow, H.-G. Sahl, N. Metzler-Nolte, Beilstein J. Org. Chem. 2012, 8, 1753-1764.

[52] H. B. Albada, P. Prochnow, S. Bobersky, S. Langklotz, P. Schriek, J.E. Bandow, N. Metzler-Nolte, ACS Med. Chem. Lett. 2012, 3, 980-984.

[53] H. B. Albada, P. Prochnow, S. Bobersky, J. E. Bandow, N. Metzler-Nolte, Chem. Sci. 2014, 5, 4453-4459.

[54] It was observed that the most active $\mathrm{FcC}(\mathrm{O})$-derivatized peptides share a C-terminal L-Arg-D-Trp- $\mathrm{NH}_{2}$, moiety whereas for the analogous $\mathrm{Rc}$ derivatives the most active compounds have an N-terminal L-Trp-D-Arg pattern. These facts probably originate from the properties of the metallic fragment and may have interesting consequences in the development of drugs with clinical applications.
[55] M. Patra, G. Gasser, D. Bobukhov, K. Merz, A. V. Shtemenko, N. MetzlerNolte, Dalton Trans. 2010, 39, 5617-5619.

[56] An additional and interesting property of these compounds, specially the Ru-AMPs is derived from the high electronic density of the metal. This electronic density allows for the visualization of the Ru-AMP in the membrane of the bacteria by using transmission electron microscopy. It was shown that $89 \%$ of the Ru-AMP locates in the cell wall. See: M. Wenzel, M. Patra, C. H. R. Senges, I. Ott, J. J. Stepanek, A. Pinto, P. Prochnow, C. Vuong, S. Langklotz, N. Metzler-Nolte, J. E. Bandow, ACS Chem. Biol. 2013, 8, 1442-1450.

[57] M. Patra, M. Wenzel, P. Prochnow, V. Pierroz, G. Gasser, J. E. Bandow, N. Metzler-Nolte, Chem. Sci. 2015, 6, 214-224.

[58] J. Wang, S. M. Soisson, K. Young, W. Shoop, S. Kodali, A. Galgoci, R. Painter, G. Parthasarathy, Y. S. Tang, R. Cummings, S. Ha, K. Dorso, M. Motyl, H. Jayasuriya, J. Ondeyka, K. Herath, C. Zhang, L. Hernandez, J. Allocco, A. Basilio, J. R. Tormo, O. Genilloud, F. Vicente, F. Pelaez, L. Colwell, S. H. Lee, B. Michael, T. Felcetto, C. Gill, L. L. Silver, J. D. Hermes, K. Bartizal, J. Barrett, D. Schmatz, J. W. Becker, D. Cully, S. B. Singh, Nature 2006, 441, 358-361.

[59] M. Patra, G. Gasser, A. Pinto, K. Merz, I. Ott, J. E. Bandow, N. MetzlerNolte, ChemMedChem 2009, 4, 1930-1938.

[60] a) M. Patra, G. Gasser, M. Wenzel, K. Merz, J. E. Bandow, N. MetzlerNolte, Organometallics 2012, 31, 5760-5771; b) M. Patra, K. Merz, N. Metzler-Nolte, Dalton Trans. 2012, 41, 112-117.

[61] M. Patra, G. Gasser, M. Wenzel, K. Merz, J. E. Bandow, N. Metzler-Nolte, Organometallics 2010, 29, 4312-4319.

[62] M. Patra, G. Gasser, M. Wenzel, K. Merz, J. E. Bandow, N. Metzler-Nolte, Eur. J. Inorg. Chem. 2011, 3295-3302.

[63] For a recent perspective of these concepts in medicinal chemistry applied to ferrocene, see: M. Patra, G. Gasser, Nat. Rev. 2017, 1, 0066.

\section{口ok? $\square$}

[64] M. S. Butler, M. A. T. Blaskovich, M. A. Cooper, J. Antibiot. 2016, 1-22. 口ok? 口

[65] Auranofin, a sugar-based $\mathrm{Au}^{\prime}$ complex that is used in the treatment of rheumatoid arthritis is also now being investigated as antimicrobial. See: S. Thangamani, M. Mohammad, M. F. N. Abushahba, T. J. P. Sobreira, V. E. Hedrick, L. N. Paul, M. N. Seleem, Sci. Rep. 2016, 6, 22571, and the pertinent references therein.

[66] One anonymous reviewer wrote "it is an observation that sometimes organometallic substitution increases activity and sometimes it does the opposite. That is exactly why thorough, careful SAR studies are needed also in this field, and (we) organometallic chemists must live up to that challenge which is obviously commonplace in (organic) medicinal chemistry". We absolutely concur with this statement supporting the necessity of taking the bio-organometallic derivatives of antibacterial drugs one step ahead. We thank him/her for this opinion.

[67] a) M. D. Burke, S. L. Schreiber, Angew. Chem. Int. Ed. 2004, 43, 46-58; Angew. Chem. 2004, 116, 48-60; b) S. L. Schreiber, Nature 2009, 457, 153-154; c) W. R. J. D. Galloway, A. Isidro-Llobet, D. R. Spring, Nat. Commun. 2010, 1, 80.

Manuscript received: November 30, 2018

Revised manuscript received: February 5, 2019

Accepted manuscript online: February 7, 2019

Version of record online: $\mathbf{\square} \mathbf{\square}, 0000$ 


\section{MINIREVIEW}

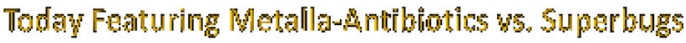
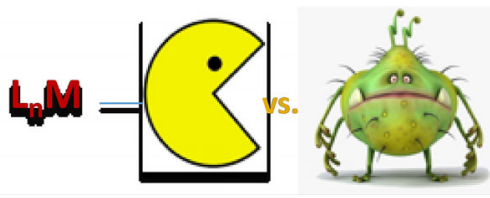

New opportunities: Misuse of antibacterial drugs has resulted in a significant increase in mortality rates due to bacterial infections and in a pressing necessi- ty of new antibacterial drugs (see figure). Bio-organometallic compounds offer an opportunity to discover new active antibacterial drugs.
Antibacterial Agents

M. A. Sierra, * L. Casarrubios, M. C. de la Torre

\section{घ- $\mathbf{0}$}

Bio-Organometallic Derivatives of Antibacterial Drugs

New strategies to overcome bacteria resistance based on the use of bioorganometallic compounds are summarized in the Minireview of M. A. Sierra et al. on page $\square$ ff. Different classes of bio-organometallic compounds, including amongst others $\beta$-lactam-derived compounds, Ag' complexes, and metalla-peptides, are discussed with respect to their synthesis and effectiveness. The usefulness of structure-activity relation studies to gain information on the mode of action of, for example, bio-organometallic antimicrobial peptides is presented.

Share your work on social media! Chemistry - A European Journal has added Twitter as a means to promote your article. Twitter is an online microblogging service that enables its users to send and read text-based messages of up to 140 characters, known as "tweets". Please check the pre-written tweet in the galley proofs for accuracy. Should you or your institute have a Twitter account, please let us know the appropriate username (i.e., @accountname), and we will do our best to include this information in the tweet. This tweet will be posted to the journal's Twitter account @ChemEurJ (follow us!) upon online publication of your article, and we recommended you to repost ("retweet") it to alert other researchers about your publication.

Please check that the ORCID identifiers listed below are correct. We encourage all authors to provide an ORCID identifier for each coauthor. ORCID is a registry that provides researchers with a unique digital identifier. Some funding agencies recommend or even require the inclusion of ORCID IDs in all published articles, and authors should consult their funding agency guidelines for details. Registration is easy and free; for further information, see http://orcid.org/.

Prof. Miguel A. Sierra http://orcid.org/0000-0002-3360-7795

Prof. Luis Casarrubios http://orcid.org/0000-0002-9054-3118

Dr. María C. de la Torre http://orcid.org/0000-0002-7310-8202 